Збірник наукових прачь Державного науково-дослідного інституту випробувань і сертифікачї̈ озброєння та військової техніки. 2019. Вип. № 2

ISSN 2706-7386

УДК 006.91

DOI: $10.37701 /$ dndivsovt.2.2019.05

Борщ В.В., Аркушенко П.Л., Вервейко О.І., Коваленко А.В., Семироз А.О. Державний науково-дослідний інститут випробувань і сертифікації озброєння та військової техніки

\title{
ДЕЯКІ ОСОБЛИВОСТІ МЕТРОЛОГІЧНОГО ЗАБЕЗПЕЧЕННЯ ВИПРОБУВАНЬ ОЗБРОЄННЯ ТА ВІЙСЬКОВОЇ ТЕХНІКИ ВІДПОВІДНО ДО СТАНДАРТІВ NАТО ТА ПРОВІДНИХ КРАЇН СВІТУ
}

У статті наведені результати дослідження стандартів NАTO та провідних країн світу з метрологічного забезпечення озброєння та військової техніки, виділено основні особливості метрологічного забезпечення випробувань відповідно до їх вимог, які представляють інтерес для метрологів України.

Ключові слова: стандарти, особливості метрологічного забезпечення, провідні краӥни світу, база даних стандартів.

Постановка проблеми. На даний час одним із фундаментальних національних інтересів України є “інтеграція ... до європейського політичного, економічного, безпекового, правового простору, набуття членства Свропейськоого Союзу та набуття членства у Організації Північноатлантичного договору..." [1], тому, потрібне створення нових зразків на основі сучасних технологій та модернізація існуючих зразків озброєння та військової техніки (ОВТ) і прийняття їх на озброєння [2].

Прийняття на озброєння (постачання) зразків ОВТ і їх допуск до експлуатації у Збройних Силах України (прийняття на озброєння (постачання)) в особливий період здійснюють за позитивними результатами відповідно державних і визначальних відомчих випробувань, які покликані дати повну та об'єктивну оцінку зразка $[3,4]$. Одним із основних видів забезпечення випробувань $є$ метрологічне забезпечення.

В Україні нормативна документація (НД) щодо метрологічного забезпечення випробувань (МЗВ) ОВТ відсутня. Питання МЗВ опосередковано висвітлені в деяких стандартах системи розроблення та поставлення продукції на виробництво и нормативних документах Міністерства обороні України, наприклад [5-8]. Більшість НД по МЗВ випущені десятки років тому і мають ряд посилань на стандарти, які скасовані і не враховують зміни в сфері виробництва зразків ОВТ.

Останнім часом, Україна веде інтенсивні роботи 3 адаптації національного законодавства в сфері метрології до міжнародних і європейських стандартів, що обумовлено iii зобов'язаннями по інтеграції в світові та європейські структури. Розроблено та впроваджено в дію сотні нормативних документів, які мають помітний вплив на МЗВ. Однак більшість НД по МЗВ останні зміни в сфері метрології не враховують.

Аналіз останніх досліджень і публікацій. Основні положення МЗВ постійно змінюються, доповнюються і вдосконалюються з метою підвищення ефективності системи випробувань.

У книзі [9] розглянуті питання метрологічного забезпечення військ, включаючи МЗВ. Однак вона містить посилання на ряд скасованих стандартів і не враховує останні зміни НД України i, тим більше, зарубіжні стандарти у сфері метрології.

Робота [10] присвячена практичним заходам щодо впровадження оцінювання невизначеності вимірювань в Збройних Силах України, що обумовлено рядом міжнародних угод, згідно яких вітчизняні нормативні документи необхідно гармонізувати 3 європейськими.

У статті [11] розглянуті питання метрологічного забезпечення випробувань авіаційної техніки, відзначена необхідність забезпечення відповідності умов випробувань реальним умовам експлуатації об'єкта та отримання достовірної вимірювальної інформації, показаний 
порядок допуску засобів вимірювань та випробувального обладнання до випробувань. Зазначені питання розглянуті, з урахуванням вимог НД Російської федерації, у сфері метрології, які останнім часом помітно відрізняються від українських.

Стаття [12] присвячена розгляду заходів системи метрологічного забезпечення у сфері оборони, реалізація яких дозволить успішно виконувати завдання метрологічного забезпечення ЗС України в умовах їх реформування з метою адаптації до сучасних вимог ринкової економіки та максимального наближення до стандартів провідних країн світу. Однак, розгляд заходів не базується на положеннях стандартів провідних країн світу.

Аналіз зазначених досліджень і публікацій показав, що в них не враховані у повному обсязі, останні зміни НД України в сфері метрології, а також більшість положень стандартів NATO та провідних країн світу.

Актуальність дослідження. Інтеграція України до NATO вимагає, зокрема, “забезпечення максимальної взаємосумісності Збройних Сил України зі збройними силами держав - членів NATO шляхом запровадження стандартів Північноатлантичного альянсу” [13]. Тому, досить актуальним є зокрема, вивчення та подальше впровадження деяких положень основних стандартів NATO та провідних країн світу в галузі метрологічного забезпечення з одночасним урахуванням НД України у сфері метрології.

Мета статті. Мета статті полягає у вивченні стандартів NATO і провідних країн світу у сфері метрології та обгрунтування, на їх основі, вимог до МЗВ, які доцільно впровадити в НД України.

\section{Виклад основного матеріалу.}

У ході дослідження, для отримання актуальної інформації про метрологічне забезпечення озброєння та військової техніки, військові стандарти NATO та провідних країн світу відбиралися за назвама i рефератами за двома напрямками: стандарти, що регламентують вимоги до випробувального та вимірювального обладнання, і стандарти, що регламентують проведення випробувань. Їх пошук проводився за базами даних стандартизації міністерств оборони цих країн, а також по спеціалізованим сайтам, одним 3 напрямків діяльності яких є інформаційний бізнес у частині забезпечення стандартами 3 країн усього світу.

До провідних країн світу віднесені Сполучене Королівство Великої Британії та Північної Ірландії, Франція, Німеччина та Сполучені Штати Америки за наступними критеріями: членство у форумі найбільших у світі індустріалізованих демократичних держав; наявність армії, яка входить в десятку найсильніших армій світу; членство у міжнародному міжурядовому військово-політичному союзі NATO; застосування стандартів країни при випробуваннях зразків озброєння та військової техніки NATO.

За результатами пошуку стандартів встановлено наступне.

База даних документів стандартизації NATO (NATO Standardization Document Database) представлена на сайті Офісу стандартизації NATO (NATO Standardization Office) [14]. На даний час ця база даних містить перелік 1144 чинних стандартів, з яких доступні для скачування лише відкриті стандарти.

Доступ до військових стандартів Сполученого Королівства можливий в он-лайн режимі на сайтах спеціалізованих баз даних по стандартизації Міністерства оборони [15]. Однак, для реєстрації треба вказати дійсний номер персоналу/служби (Staff/Service Number), який видається співробітникам міністерства оборони та державним службовцям Сполученого Королівства. Військові стандарти мають ідентифікатор DEFSTAN.

У Франції інформація про нові, змінені, скасовані військові стандарти і специфікації розповсюджується у межах внутрішньої мережі Інтранет через веб-сайт для стандартів оборони. Секретні стандарти представляють тільки у друкованому вигляді. Військові стандарти мають, в основному, ідентифікатор CEN або GAM.

В якості військових стандартів у Німеччині, в основному, використовують відповідні цивільні стандарти. Якщо цивільні стандарти не можуть застосовуватися, то сектор озброєнь спочатку намагається ввести конкретні військові вимоги в існуючі цивільні стандарти, які 
розроблюються. У цьому випадку військові фахівці беруть участь у відповідних цивільних комітетах Німецького інституту по стандартизації (Deutsches Institut für Normung (DIN)). У результаті такої співпраці розробляються відповідні цивільні стандарти. Тільки в тому випадку, якщо вимоги галузі оборони в цивільних стандартах врахувати не видається можливим, фахівці відповідної галузі можуть розробити військові стандарти (стандарти VG). Це робиться відповідно до правил DIN. Після появи цивільних стандартів, які враховують усі вимоги до оборонної галузі, відповідні військові стандарти скасовують. Військові стандарти Німеччини можливо придбати у фірмі Beuth Verlag, яка є одним з провідних європейських видавців технічних стандартів і провідним в Свропі постачальником повного спектру технічної інформації для всіх секторів і професій [16]. Фірма Beuth Verlag є дочірнім підприємством DIN. Однак, на сайті фірми Beuth Verlag надається інформація тільки після реєстрації з оплатою послуг.

Документи зі стандартизації Міністерства оборони США включають:

- оборонні стандарти, специфікації, стандарти і довідники. Оборонні стандарти зазвичай мають ідентифікатор MIL. Існує п'ять різних типів: стандартна практика, стандарти інтерфейсів, стандарти критеріїв проектування, стандарти методів випробувань і стандарти виробничих процесів;

- описи комерційних об'єктів, а також федеральні специфікації і стандарти, розроблені відповідно до узгоджених процедур Федерального керівництва зі стандартизації;

- недержавні стандарти, розроблені відповідно до процедур консенсусу організацій зі стандартизації приватного сектора;

- стандарти, розроблені в рамках НАТО та інших багатонаціональних органів безпеки.

База даних ASSIST Міністерства оборони США характеризується найкращими параметрами і можливостями [17]. Вона містить 224739 PDF-файлів, пов'язаних 386856 проіндексованими документами i надає безкоштовний доступ до відкритих технічних документів у вигляді анотації, PDF- файлів базового документу і всіх його змін. Зокрема, на стандарт MIL_STD-810 надається 19 PDF-файлів, причому, більшість 3 них має обсяги понад 1000 сторінок.

Надання інформації про стандарти, включаючи військові, та їх продаж здійснюють близько 10 спеціалізованих сайтів, серед яких, на думку авторів, кращим є сайт фірми SAI Global, одним з напрямків діяльності якої $є$ інформаційний бізнес у частині забезпечення стандартами країн усього світу [18]. База даних стандартів цієї фірми містить понад один мільйон стандартів від 300 організацій з розробки і випуску стандартів. На жаль, інформація про стандарти України в цій базі відсутня. Цей сайт безкоштовно надає довідкову інформацію: позначення і найменування стандарту; зміст; реферат; статус; видання; які стандарти замінює; стандарти, на які є посилання у цьому документі; стандарти, які мають посилання на цей документ. Наявність інформації про посилання є дуже корисною, оскільки, побічно характеризує рівень розробки стандарту, галузі його застосування та актуальність. Так, наприклад, військовий стандарт CШA MIL-STD-810G, який широко використовується у світовій практиці для випробування виробів військового та цивільного призначень, містить посилання на близько 1500 стандартів різних країн і міжнародних організацій, а, в свою чергу, 19 стандартів різних країн містять посилання на цей стандарт. 3 метою спрощення пошуку потрібних стандартів на сайті надається можливість їх пошуку за різними критеріями, зокрема "metrological and measurement in general" (метрологія та вимірювання в цілому).

Метрологічне забезпечення ОВТ в НАТО, в основному, регламентовано прямо і побічно стандартами STANAG 4107 "Mutual Acceptance of Government Quality Assurance and Usage of the Allied Quality Assurance Publications" [19], STANAG 4370 "Environmental testing" [20], STANAG 4704 "NATO requirements for calibration support of test and measurement equipment" [21]. В Україні, на основі цих стандартів, методом підтвердження прийнято 18 національних стандартів, які представлені на мовах оригіналу (англійською та французькою мовами). Однак, практичне впровадження цих національних стандартів ускладнене їх 
великим обсягом, зокрема, STANAG 4370 займає 2897 сторінок тексту, а також складністю ïx перекладу на українську мову, так, наприклад, переклад слова "standard" має 17 варіантів (див. https://context.reverso.net/переклад/англійська-українська/Standard). Тому, для перекладу стандартів необхідно добре знати мови і розуміти суть технічної проблеми. На особливу увагу заслуговує практика Національного агентства 3 акредитації України, яка 3 метою надання методичної підтримки затверджує та впроваджує в діяльність переклади, які $є$ неофіційними та носять інформаційний характер, при цьому рекомендується використовувати стандарт, прийнятий методом підтвердження. Так, зокрема, переклад стандарту ДСТУ ISO/IEC 17025:2017 зробив доктор фізико-математичних наук, професор.

Під час дослідження було проведено переклад, вивчення, аналіз та узагальнення зазначених стандартів, що дозволило виділити такі особливості метрологічного забезпечення OBT:

- системи вимірювання та калібрування повинні відповідати вимогам ISO 10012:2003 (в Україні діє ДСТУ ISO 10012:2005);

- калібрувальні послуги повинні надаватися у відповідності 3 ISO 17025:2017 (в Україні діють ДСТУ ISO 17025:2005 і ДСТУ ISO 17025:2017);

- країни NATO та їх партнери погоджуються: активізувати і розширювати міжнародне співробітництво 3 питань метрології, включаючи управління випробувальним i вимірювальним обладнанням; спільно працювати для встановлення системи обміну інформацією про випробувальне та вимірювальне обладнання; спільно працювати, використовуючи міжлабораторні порівняння;

- сумарна невизначеність вимірювання всієї системи випробувань, включаючи статистичні помилки, не повинна перевищувати однієї третини від зазначеного рівня невизначеності ОВТ;

- допускається калібрувати вимірювальне та випробувальне обладнання відповідно до вимог лабораторних стандартів, які забезпечують простежуваність до національних еталонів через первинні еталони.

Метрологічне забезпечення ОВТ у провідних країнах світу прямо або побічно регламентують 22 виявлених стандарти, з яких виділено 6 основних [22-27].

У стандарті [22] все обладнання, що має метрологічні характеристики (OMX), розділене на дві групи, а саме:

- випробувальне, вимірювальне та діагностичне обладнання (Test, Measurement and Diagnostic Equipment (TMDE)) - будь-яка система або пристрій, що використовується для випробувань, вимірювань, оцінки, перевірки або іншого аналізу матеріалів, обладнання або системи для виявлення та/або ізоляції будь-якої фактичної або потенційної несправності або визначення відповідності специфікаціям, встановленим у технічних документах.

- вбудоване обладнання для випробувань (Built-in-Test Equipment (BITE)) - будь-який пристрій, який є частиною системи, підсистеми або обладнання і використовується 3 метою тестування.

При визначенні метрологічних характеристик OBТ стандарт вимагає враховувати коефіцієнт невизначеності (Test Uncertainty Ratio (TUR)), який характеризує співвідношення між максимально допустимою невизначеністю параметра або характеристики ОВТ, що підлягають вимірюванням при випробуваннях, та невизначеністю, що забезпечує обладнання, яке має метрологічні характеристики. Цей коефіцієнт враховує можливі джерела помилок, зокрема, температуру, вологість, невизначеності типу А, невизначеності типу В тощо. Мінімальне значення TUR повинно бути 4 до 1. Якщо вказане значення не може бути досягнуте, то надають документальне обгрунтування для меншого значення TUR. При аналізі лише вхідних впливів, які не використовуються для характеристики TMDE aбо BITE, мінімальне значення TUR 1 до $1 є$ прийнятним.

Також, відповідно до даного стандарту на всіх етапах життєвого циклу ОВТ слід виконувати такі загальні вимоги щодо вимірювання: 
- всі параметри, які підлягають вимірюванню, повинні бути ідентифіковані та задокументовані;

- вбудоване програмне забезпечення, необхідне для вимірювання або тестування, повинно бути забезпечено анотацією за версією, номером редакції і датою перегляду. Будьякі зміни у ньому повинні бути задокументовані;

- калібрування і вимірювання виконуються за необхідності, відповідно до встановлених вимог щодо підтримки працездатності системи та підсистеми;

- всі параметри повинні вимірюватися таким чином, щоб мінімізувати кількість і тривалість необхідних випробувань;

- повинна бути задокументована метрологічна простежуваність всіх параметрів системи та підсистеми.

Керівництво користувача [23] призначене для надання споживачам більш глибокого розуміння вимог MIL-STD-1839D, а також для надання допомоги у забезпеченні однакової оцінки відповідності виробів індивідуальним вимогам.

Зведені вимоги до калібрування та вимірювання [24] деталізують вимоги до вимірювальної системи, підсистеми або обладнання; TMDE; стандартів та обладнання калібрування, які необхідні для забезпечення метрологічної простежуваності всіх вимірювань. Метрологічна простежуваність здійснюється через окремі військові відомчі метрологічні та калібрувальні програми та методики до затверджених національних стандартів. Дані, представлені в [24], вимагають періодичного оновлення, щоб врахувати зміни в конструкції та технології, що зумовлені вдосконаленням системи та які впливають на вимоги до вимірювальної системи або TMDE.

Військовий стандарт [25] регламентує ряд стандартних параметрів, для великої кількості лабораторних випробувань військової продукції, які дозволяють визначити стійкість широкого переліку обладнання до різних впливів в не польових (лабораторних) умовах, наприклад: пил, пісок, вологість, тиск, падіння, вібрація, тощо.

Цей стандарт схвалений для використання всіма департаментами та агентствами Міністерства оборони США. Проходження випробувань по ньому є необхідною умовою для участі у замовленнях на поставку техніки і комплектуючих. Спочатку даний стандарт створювався для випробувань військової продукції, але згодом став широко застосовуватися і для випробувань цивільної продукції.

Таким чином метрологічне забезпечення випробувань за стандартами [22-27] представлене в узагальненому вигляді, регламентує наступні вимоги:

- все випробувальне і вимірювальне обладнання повинно бути відкалібровано відповідно до лабораторних стандартів 3 визначенням метрологічної простежуваності до національних еталонів через первинні еталони;

- інтервали калібрування повинні відповідати вимогам ANSI / NCSL Z540.1 або ISO 10012-1:1992;

- сумарна похибка або невизначеність вимірювань випробувального та вимірювального обладнання не повинна перевищувати однієї третини від похибки або невизначеності параметра або характеристики досліджуваного об'єкта, якщо інше не обумовлено в методиці випробувань.

Висновки. Дослідження та узагальнення вимог стандартів NATO та провідних країн світу дозволяє зробити наступні основні висновки: системи вимірювання та калібрування повинні відповідати вимогам ISO 10012:2003; калібрувальні послуги слід надавати у відповідності з ISO 17025:2017; поділ калібрувального і вимірювального обладнання на типи відрізняється від прийнятого в Україні; метрологічна простежуваність калібрувального і вимірювального обладнання повинна бути задокументована; мінімальне значення TUR повинно бути 4 до 1, якщо документальне обгрунтування для меншого значення TUR не надано; інтервали калібрування повинні відповідати вимогам ISO 10012-1:1992; терміни “єдність вимірювань” та “достовірність контролю” в зазначених стандартах не застосовуються. 


\section{СПИСОК ЛІТЕРАТУРИ}

1. Про національну безпеку України: Закон України від 21.06.2018 №2469-VIII // Відомості Верховної Ради України. - 2018. - № 31. - ст.241. - 35 с.

2. Стратегічний оборонний бюлетень України // Указ Президента України від 06.06.2016. - № 240/2016. - 23 с.

3. Порядок розроблення, освоєння та випуску нових видів продукції оборонного призначення, а також припинення випуску існуючих видів такої продукції // Постанова Кабінету Міністрів України № 120. - [Чинний від 2013-02-20]. - 7 с.

4. Тимчасова інструкція 3 організації та проведення визначальних відомчих випробувань озброєння та військової техніки // Наказ заступника Міністра оборони України. . - [Чинний від 2019-04-03]. - 15 с.

5. OTT 1.1.7-89.

6. Державна система стандартизації військової техніки. Метрологічне забезпечення озброєння та військової техніки. Основні положення: ДСТУ В 1.2 - 95. - [Чинний від 1997-01-01]. - К.: Держстандарт України, 1995. - 39 с. (Державний стандарт України).

7. Система разработки и постановки продукции на производство военной техники. Испытания опытных образцов изделий и опытных ремонтных образцов изделий. Основные положения: ГОСТ В 15.210-78. - Введ. 1978-01-01. - М.: Изд-во Государственный комитет СССР по стандартам, 1978. - $41 \mathrm{c.}$

8. Правила метрологічного забезпечення державної авіації України // Наказ міністра оборони України № 812. - [Чинний від 2013-11-27]. - 51 с.

9. Кузнецов І.Б. Організація метрологічного забезпечення військ (сил). / І.Б. Кузнецов, П.М. Яблонський. - К.: НУОУ, 2009. - 356 с.

10. Пашкевич І.Д. Впровадження оцінювання невизначеності вимірювань в метрологічних та вимірювальних лабораторіях збройних сил України / І.Д. Пашкевич, С.М. Шевкун // Системи обробки інформації, 2009. - № 5 (79). - С. 120-122.

11. Шевченко М.И. Вопросы метрологического обеспечения испытаний авиационной техники / М.И. Шевченко, Л.Ф. Моисеев // Известия Самарского научного центра Российской академии наук. - 2014. - Том 16. - № 1(2). - С. 561-565.

12. Гудима В.П. Фактори підвищення ефективності метрологічного забезпечення у сфери оборони / В.П. Гудима // Збірник наукових праць Харківського університету Повітряних Сил. - 2014. - №1 (38). - C.217-220.

13. Стратегія національної безпеки України // Указ Президента України від 26.05.2015. - № 287/2015. - 18 c.

14. List of Current NATO Standards. [Електронний ресурс]. // NSDD. - Режим доступу: https://nso.nato.int/nso/nsdd/listpromulg.html. - дата доступу: 08.01.2020.

15. Ministry of Defence. [Електронний ресурс]. - Режим доступу: www.dstan.dii.r.mil.uk. - дата доступу: 18.12.2019.

16. Standards Collection. [Електронний pecypc]. // Beuth (publishing DIN). - Режим доступу: https://www.beuth.de/de. - дата доступу: 19.12.2019.

17. Quick Search. [Електронний ресурс]. // ASSIST. - Режим доступу: https://quicksearch.dla.mil/qsOverview.aspx. - дата доступу: 17.12.2019.

18. Standards. [Електронний pecypc]. // SAI GLOBAL/ - Режим доступу: https://www.saiglobal.com/en-au/standards/. - дата доступу: 24.12.2019.

19. Mutual Acceptance of Government Quality Assurance and Usage of the Allied Quality Assurance Publications (AQAP): STANAG 4107. / Edition 11. - [Чинний від 2019-01-15]. - Brussels: NSO, 2019. -6 c.

20. Environmental testing: STANAG 4370. / Edition 6. - [Чинний від 2016-12-08]. - Brussels: NSO, 2016. $-6 \mathrm{c}$.

21. NATO requirements for calibration support of test and measurement equipment: STANAG 4704. / Edition 2. - [Чинний від 2017-12-01]. - Brussels: NSO, 2017. - 6 c. 
22. Department of defense. Standard practice. Calibration and measurement requirements: MIL-STD-1839D. - [Чинний від 2010-12-06]. - USA : DoD, 2010. - 12 c.

23. Department of defense. Handbook. Calibration and measurement requirements: MIL-HDBK-1839A. - [Чинний від 2000-11-27]. - USA : DoD, 2000. - 44 c.

24. Data item description. Calibration and measurements requirements summary (CMRS): DI-QCIC-80278C. - [Чинний від 2017-01-23]. - USA: DoD, 2017. - 18 c.

25. Department of defense. Test method standard. Environmental engineering considerations and laboratory tests: MIL-STD-810D. - [Чинний від 2014-15-05]. - USA: DoD, 2010. - 12 c.

26. Measurement and calibration system requirements for ministry of defense test and measurement equipment (три частини): DEFSTAN 05-55 (2016) : 2016. - [Чинний від 2016-01-01]. - UK: Ministry of Defence Standards, 2015. - 48 c.

27. Documentation of calibration services: VG 96910 : 2015. - [Чинний від 2016-01-01]. - Deutschland: Federal Ministry of Defence, 2015. - 7 c.

\section{Борщ Вячеслав Вікторович}

старший науковий співробітник Державного науково-дослідного інституту випробувань і сертифікації озброєння та військової техніки, Чернігів, Україна https://orcid.org/0000-0002-8851-4553

0462-67-94-29

\section{Аркушенко Павло Леонідович}

кандидат технічних наук, провідний науковий співробітник Державного науково-дослідного інституту випробувань і сертифікації озброєння та військової техніки, Чернігів, Україна

https://orcid.org/0000-0002-1902-696X

0462-67-94-29

\section{Вервейко Олександр Іванович}

кандидат технічних наук, провідний науковий співробітник Державного науково-дослідного інституту випробувань і сертифікації озброєння, та військової техніки, Чернігів, Україна

https://orcid.org/0000-0002-7951-2169 0462-67-94-29

\section{Коваленко Андрій Володимирович}

начальник науково-дослідного відділу Державного науково-дослідного інституту випробувань i сертифікації озброєння та військової техніки, Чернігів, Україна https://orcid.org/0000-0001-6067-5286 0462-67-94-29

\section{Vyacheslav Borshch}

Senior Researcher of State Scientific Research Institute of Armament and Military Equipment Testing and Certification, Chernihiv, Ukraine https://orcid.org/0000-0002-8851-4553 0462-67-94-29

\section{Pavlo Arkushenko}

Candidate of Technical Sciences, Lead Researcher of State Scientific Research Institute of Armament and Military Equipment Testing and Certification, Chernihiv, Ukraine https://orcid.org/0000-0002-1902-696X 0462-67-94-29

\section{Alexander Verveyko}

Candidate of Technical Sciences, Lead Researcher of State Scientific Research Institute of Armament and Military Equipment Testing and Certification, Chernihiv, Ukraine https://orcid.org/0000-0002-7951-2169 0462-67-94-29

\section{Andrii Kovalenko}

Chief of Section of State Scientific Research Institute of Armament and Military Equipment Testing and Certification, Chernihiv, Ukraine https://orcid.org/0000-0001-6067-5286 0462-67-94-29 
Збірник наукових прачь Державного науково-дослідного інституту випробувань і сертифікачії озброєння та військової техніки. 2019. Вип. № 2

\section{Семироз Андрій Олегович}

науковий співробітник Державного науководослідного інституту випробувань і сертифікації озброєння та військової техніки, Чернігів, Україна https://orcid.org/0000-0003-3249-639X 0462-67-94-29

\section{Andrii Semiroz}

Researcher of State Scientific Research Institute of Armament and Military Equipment Testing and Certification, Chernihiv, Ukraine https://orcid.org/0000-0003-3249-639X 0462-67-94-29

\title{
SPECIAL ASPECTS OF THE METROLOGICAL SUPPORT OF ARMAMENT AND MILITARY EQUIPMENT TESTS IN ACCORDANCE WITH STANDARDS OF NATO AND WORLD LEADING NATIONS
}

\author{
V. Borshch, P. Arkushenko, A. Verveiko, A. Kovalenko, A. Semiroz
}

The article deals with the results of the study of NATO standards and world leading nations in the metrological support of armament and military equipment, identifies the main features of metrological support of tests in accordance with their requirements, which may be adventagous to Ukrainian metrologists. The purpose of the article is to identify the features of the standards that determine the requirements for metrological support for armament and military equipment testing based on their analysis. NATO Metrological Assurance is generally regulated, directly and indirectly, by STANAG 4107 Mutual Acceptance of Government Quality Assurance and Usage of Allied Quality Assurance Publications, STANAG 4370 Environmental Testing, STANAG 4704 NATO requirements for calibration support of test and measurement equipment. In Ukraine, on the basis of these standards (presented in the original languages - English and French), 18 national standards have been adopted by the method of acknowledgement. The MIL-STD-810G metrology test specification, presented in a generalized form, regulates the requirements for testing and measuring equipment, calibration intervals and total error (or measurement uncertainty) of test and measuring equipment. According to NATO standards, all metrological equipment is divided into 4 types, which are grouped into two groups, namely: 1) Test, Measurement, and Diagnostic Equipment (TMDE); 2) Embedded Built-inTest Equipment (BITE). MIL-HDBK-1839A Calibration and Measurement Requirements Summary (CMRS) details the requirements: for the measuring system, subsystem or equipment; TMDE in its turn deals with the standards and calibration equipment necessary to ensure the metrological traceability of all measurements through separate military departmental metrology and calibration programs to the approved national standards. The MIL-STD-810G military standard regulates a number of standard parameters for a large number of laboratory tests of military products, which allows to determine the resistance of a wide range of equipment to various impacts. The peculiarities of the analysis of the U.S. standards should be taken into account when elaborating the regulatory documents for metrological testing in the Armed Forces of Ukraine.

Keywords: standards, special aspects of metrological support, world leading nations, standardization organizations. 